\title{
TIPIC syndrome
}

Figure 1 Initial imaging

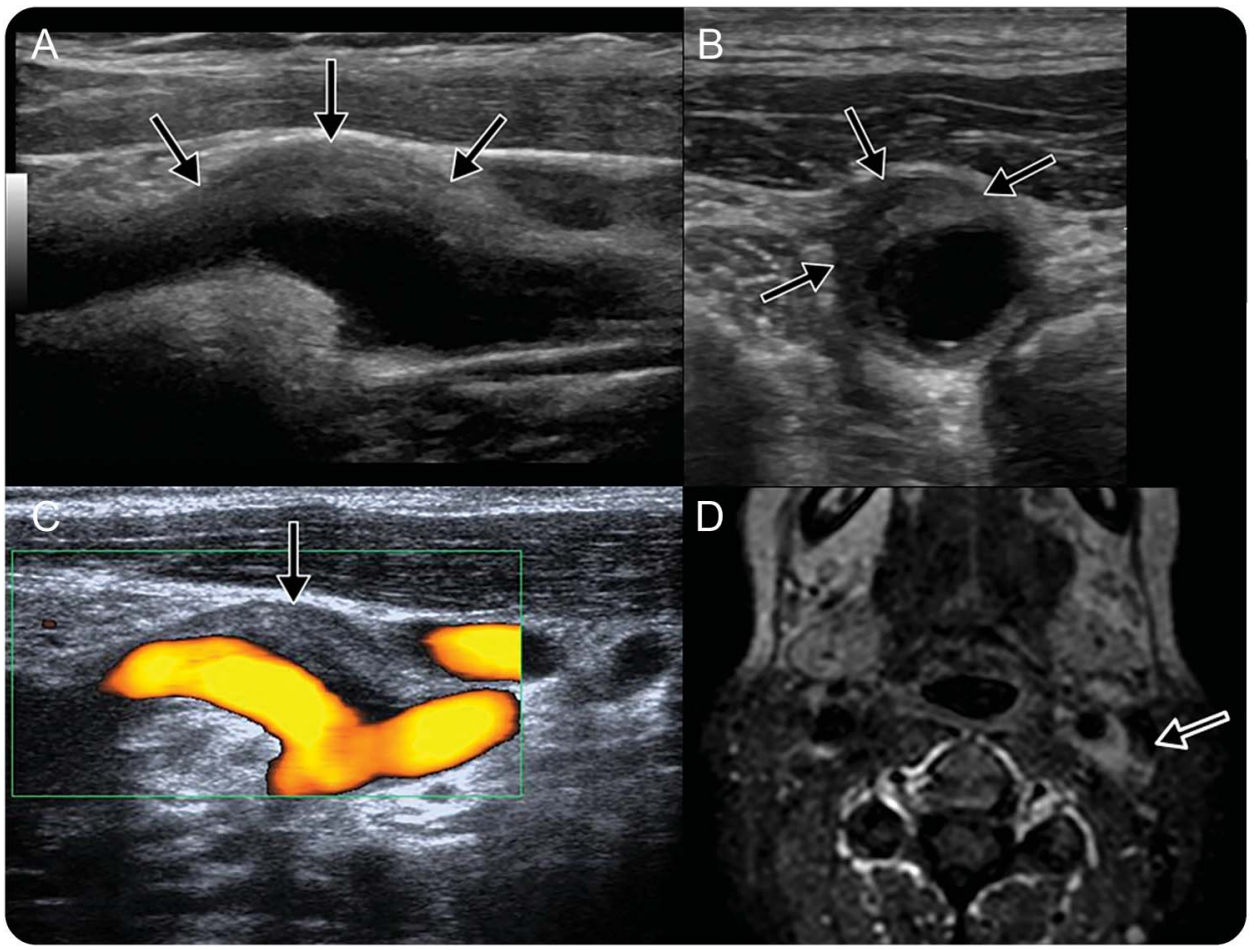

Ultrasound in B-mode (A, B) and color Doppler mode (C) and axial postcontrast T1-weighted MRI (D) show eccentric enhancing abnormal soft tissue (arrows) surrounding the left carotid artery bifurcation, with mild lumen caliber narrowing and no hemodynamic change.

A 31-year-old woman presented with left acute cervical pain. Cervical imaging showed a large pericarotid infiltration (figure 1). A diagnosis of transient perivascular inflammation of the carotid artery (TIPIC) syndrome was made. The patient received steroids with full clinical recovery 12 days after onset. The

\section{Figure 2 Follow-up ultrasound}

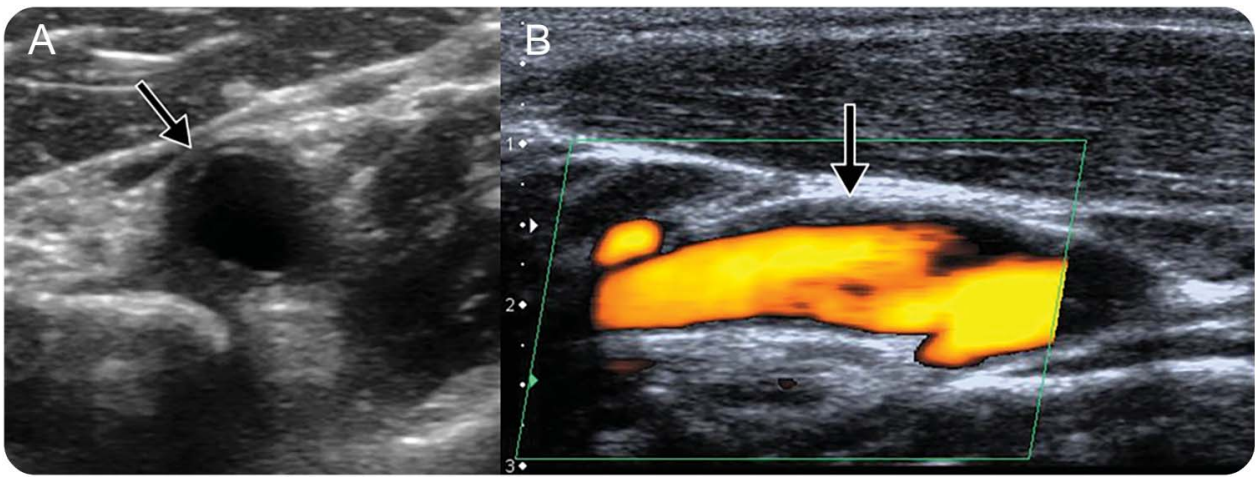

Follow-up ultrasound in B-mode (A) and color Doppler mode (B) show striking decrease of the perivascular infiltration. 
follow-up ultrasound showed striking decrease of the perivascular infiltration, confirming the diagnosis (figure 2).

TIPIC is a newly recognized syndrome ${ }^{1}$ that describes a distinct clinicoradiologic entity previously diagnosed as carotidynia, ${ }^{2}$ consisting of transient perivascular inflammation at the level of the carotid bifurcation. Its physiopathology is unknown. Anti-inflammatory drugs lead to a quick full clinical recovery.

Augustin Lecler, MD, MSc, Mickael Obadia, MD, Jean-Claude Sadik, MD

From the Departments of Radiology (A.L., J.-C.S.) and Neurology (M.O.), Fondation Ophtalmologique Rothschild, Paris, France. Study funding: No targeted funding reported.

Disclosure: The authors report no disclosures relevant to the manuscript. Go to Neurology.org for full disclosures.

Correspondence to Dr. Lecler: alecler@for.paris

1. Lecler A, Obadia M, Savatovsky J, et al. TIPIC syndrome: beyond the myth of carotidynia, a new distinct unclassified entity. AJNR Am J Neuroradiol 2017;38:1391-1398.

2. Biousse V, Bousser MG. The myth of carotidynia. Neurology 1994;44:993-995.

\section{WriteClick ${ }^{\circledR}$ rapid online correspondence}

Have a comment on a recent Neurology ${ }^{\circledR}$ article you would like to share? Now it is easier and more convenient. Neurology.org has launched WriteClick on the home page and sidebars of each article to encourage remarks and debate among users.

WriteClick is restricted to comments about studies published in Neurology within the last eight weeks.

Learn more at Neurology.org/letters

\section{Visit the Neurology ${ }^{\circledR}$ Resident \& Fellow Website}

Click on Residents \& Fellows tab at Neurology.org.

Now offering:

- Neurology ${ }^{\circledR}$ Resident \& Fellow Editorial team information

- "Search by subcategory" option

- E-pearl of the Week

- RSS Feeds

- Direct links to Continuum ${ }^{\circledR}$, Career Planning, and AAN Resident \& Fellow pages

- Recently published Resident \& Fellow articles

- Podcast descriptions

(1.) Find Neurology ${ }^{\circledR}$ Residents \& Fellows Section on Facebook: http://tinyurl.com/o8ahsys

twitter Follow Neurology ${ }^{\circledR}$ on Twitter: http://twitter.com/GreenJournal 


\title{
Neurology
}

\author{
TIPIC syndrome \\ Augustin Lecler, Mickael Obadia and Jean-Claude Sadik \\ Neurology 2017;89;1646-1647 \\ DOI 10.1212/WNL.0000000000004502
}

This information is current as of October 9, 2017

$\begin{array}{ll}\begin{array}{l}\text { Updated Information \& } \\ \text { Services }\end{array} & \begin{array}{l}\text { including high resolution figures, can be found at: } \\ \text { http://n.neurology.org/content/89/15/1646.full }\end{array} \\ \text { References } & \text { This article cites } 2 \text { articles, } 2 \text { of which you can access for free at: } \\ & \text { http://n.neurology.org/content/89/15/1646.full\#ref-list-1 } \\ \text { This article, along with others on similar topics, appears in the } & \\ \text { following collection(s): } & \text { MRI } \\ \text { http://n.neurology.org/cgi/collection/mri } \\ \text { Other cerebrovascular disease/ Stroke } \\ \text { http://n.neurology.org/cgi/collection/other_cerebrovascular_disease_st } \\ \text { roke } \\ \text { Secondary headache disorders } \\ \text { http://n.neurology.org/cgi/collection/secondary_headache_disorders } \\ \text { Ultransound } \\ \text { http://n.neurology.org/cgi/collection/ultrasound } \\ \text { Information about reproducing this article in parts (figures,tables) or in } \\ \text { its entirety can be found online at: } \\ \text { http://www.neurology.org/about/about_the_journal\#permissions } \\ \text { Information about ordering reprints can be found online: } \\ \text { http://n.neurology.org/subscribers/advertise }\end{array}$

Neurology ${ }^{\circledR}$ is the official journal of the American Academy of Neurology. Published continuously since 1951, it is now a weekly with 48 issues per year. Copyright @ 2017 American Academy of Neurology. All rights reserved. Print ISSN: 0028-3878. Online ISSN: 1526-632X.

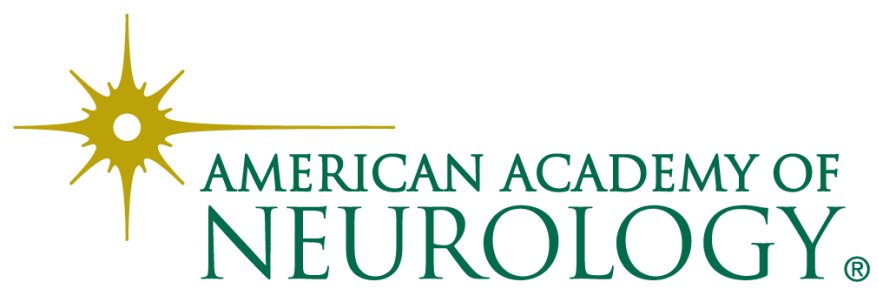

